\title{
ADYGEA IS A PEARL OF THE CAUCASUS, NATIONAL FEATURES OF ETHNOS FROM ORIGINS TO MODERNITY
}

\author{
(c) Yulia A. Petrova, Milana R. Kemova
}

\author{
Rostov State University of Economics (RSEU), Rostov-on-Don, Russian Federation \\ science-almanac@mail.ru
}

The diverse culture of the Republic of Adygea is revealed. Today Adygea plays a very important role in the formation of the spiritual appearance of man. More than 100 peoples live here in friendship and mutual understanding, where social, economic and national problems are successfully solved. The study provides a theoretical rationale for the validity of the conceptual unity of scientific rationality and of the figurative language of the ancient multifaceted culture and art of Adygea. According to the scientists, long-standing Adighe traditions and customs reflected the emergence of an individual system of personality values. The Adighe people honor their rituals, customs, on the basis of which a moral code of the Adygeis, called "Adygagye" is formed, acting as the core of the Adighe culture. The sound of Adighe music, the fighting qualities and sophistication of Circassian weapons, the splendor of the national costume, of the national dance, the peculiarities of traditional cuisine anciently make up the treasure trove of the culture of the Adygeis. The detailed examination of the national characteristics of ethnos actualizes the possibility and necessity to find such form of culture and art that would meet the needs of a man of the modern era.

Key words: North Caucasus, Republic of Adygea, culture, adygagye, adygae habze, Adygeis, Circassians.

\section{[Ю.А. Петрова, М.Р. Кемова Адыгея - жемчужина Кавказа, национальные особенности этноса от истоков к современности]}

Раскрывается многообразная культура Республики Адыгея. Сегодня Адыгея играет весьма существенную роль в формировании духовного облика человека. Здесь в дружбе и взаимопонимании живут более ста народов, где успешно решаются социальные, экономические и национальные проблемы. В исследовании дано теоретическое обоснование действенности концептуального единства научной рациональности и образного языка древней многогранной культуры и искусства Адыгеи. Согласно исследованиям ученых, в давних адыгейских традициях и обычаях отражено становление индивидуальной системы ценностей личности. Адыгейский народ чтит свои ритуалы, обычаи, на базе которых формируется морально-нравственный кодекс адыгов, именуемый «Адыгагъэ», выступающий ядром адыгской культуры. Звучание адыгской музыки, боевые качества и изысканность черкесского оружия, великолепие национального костюма, национального танца, особенности традиционной кухни издревле составляют сокровищницу культуры адыгов. Детальное рассмотрение национальных особенностей этноса актуализирует возможность и необходимость найти такую форму культуры и искусства, которая отвечала бы потребности человека современной эпохи.

Ключевые слова: Северный Кавказ, Республика Адыгея, культура, адыгагъэ, адыгэ хабзэ, адыги, черкесы.

Yulia A. Petrova - Ph.D. in Philosophy, Associate Professor, Rostov State University of Economics (RSEU), Rostov-on-Don, Russian Federation.

Milana R. Kemova - second-year student, Rostov State University of Economics (RSEU), Rostov-on-Don, Russian Federation.

Петрова Юлия Андреевна - кандидат философрских наук, доцент, Ростовский государственный экономический университет (РИНХ), г. Ростов-на-Дону, Российская Федерация.

Кемова Милана Руслановна - студентка второго курса, Ростовский государственный экономический университет (РИНХ), г. Ростов-на-Дону, Российская Федерация. 
The Republic of Adygea extended from the Krasnodar Reservoir to the East, and then turned a narrow lane to the South, to the mountains. On the territory of the republic there are Adygeisk and Maikop. Maikop is the capital of the Republic of Adygea, its administrative, economic and cultural center. The name of the city is derived from the Adighe word "Myekjuape", which can be translated as "a settlement in the mouth of the river flowing in the valley of wild apple trees" [4, 346 p.]. The town is located at the foot of the western branches of the Greater Caucasus Mountain Range, on the right bank of the Belaya river, of the tributary of the Kuban river. It is inhabited by more than 160,000 inhabitants. More than 80 nationalities live in the capital [4, pp. 3-5].

The Republic of Adygea has its own coat of arms and flag. The coat of arms is a circle framed from above with a ribbon with the inscription "the Republic of Adygeya" in Russian and Adyghe. In the middle of the ribbon there is a star, on the lateral sides there are leaves of oak, maple, ears of wheat, ears of corn. The circle is closed by the abbreviation of the words "Russian Federation" (the letters RF), above which the national table "ane" $[4,14$ p.] with bread and salt is shown. In the middle of the circle there is the main character of the Nart sagas Sausrykyo on a fiery horse. The horse expresses a desire to link the past, the present and the future in their historical development.

The flag of the Republic of Adygea is a green canvas, on it there are 12 gold-sewed stars and 3 gold crossed arrows directed with tips up, where 12 stars mean 12 Adighe (Circassian) tribes. Green symbolizes life, eternity, as well as one of the natural features of the republic, in which almost forty percent of the territory is occupied by forests. In Adygea the unique beauty of nature, legends of old and bright original culture are intertwined. Here there was the Great Silk Road, the Nart sagas formed. Ethnos the Adygeis have been living on this land since ancient times.

From the earliest times the spiritual culture of the Adygeis includes various ideas about man and the surrounding world, about the earth, vegetation, animal world, representations about the universe. It captivates everyone who has ever come into contact with it. The sound of Adighe music, the sophistication of Circassian weapons, the splendor of the national costume, all these anciently make up the treasure trove of Adighe culture.

Few corners of Russia have such natural diversity as Adygea. On the small territory of the republic all natural complexes of Russia are collected. Mountain forests and subalpine meadows, beautiful plateau and snow peaks of the Greater Caucasus Mountain Range, the glaciers of which feed rapid rivers with cascades of thresholds and falls, deep cramped, numerous caves, rare plants and animals, which once appeared from the South. The nature of Adygea leaves an unforgettable impression in the hearts of visitors [2, pp. 910].

The Adygeis honor and respect their traditional rituals, which inform about the birth of a new family, of a new person, about the completion of the construction of a new residential building, about the harvest, etc. The moral code of the Adygeis, called "Adygagye", acts as the core of the Adighe culture. Adygagae is literally translated as "adygia", meaning translation is "Adighe ethics". "Adygagae" is a detailed ethical system that includes humanity, reverence, reason, courage and honor and that defines the nature of views on good and evil, fair and unfair, decent and obscene. In the past, when there were no written works, "adygagae" [2, 4 p.] covered all aspects of the historical and spiritual life of the Adygeis. This preserved them, as well as the Circassian diaspora in foreign countries during the years of the serious events of the 19th-20th centuries. They provided historical memory, the connection of the past with the present, the internal cohesion of the people and their unity with the homeland. The Adygeis perceive the loss of adygagae as the loss of their national identity, their native language. Its preservation is important for the whole Adighe, Circassian world [7]. 
Since the language forms thoughts, the nature of communicative decisions, as well as of attitudes, identity and estimated results of this choice [9], the Adyghe language is the language of this ethnic group. It belongs to the West Caucasus group of Caucasian languages and has four main dialects:

- Abadzekhsky;

- Bzhedugsky;

- Temirgoyevsky (Chemguysky);

- Shapsugsky.

In the Republic of Adygea there are two state languages: Russian and Adyghe. Language reflects our culture, psyche and mindset [6, 90 p.] and the Adygeis have been continuing to maintain their linguistic characteristics to date. The territory has a state program for the preservation and development of state languages, under which the children learn modern Adyghe at pre-school educational institutions, schools and vocational training institutions. Books and game manuals are published in two state languages. Celebrations of Days of the Adyghe Language and Writing and Days of the Russian Writing and Culture are held in the Republic annually [5].

Another national feature of ethnos is a national cuisine. As the Adighe saying goes, tasty food amuses a man. The traditions associated with food have their own ethnic specificities. If you go back a few thousand years, numerous Circassian dishes are clearly reflected in history, the Nart sagas, proverbs and fairy tales. The Adygeis like many other nationalities were always distinguished by the preparation of a variety of dishes, surprised their guests and did not get into awkward situations due to the lack of food.

Legendary Narts always had something to surprise the guest. In the past, the Adygeis associated joint eating with the rites of sacrifice, it had a special, magical meaning. Food was considered as God's grace. Stepping on food, throwing away, or even speaking about it dismissively were forbidden. The joint intake of food and drink was something that sealed the bonds of friendship. To reject the treat was an indelicacy, it was necessary to accept it with gratitude, or at least to try a small part, even if you were not hungry. Refusal could be taken as disrespect for the householder or even as an announcement of enmity.

The set table was also of great importance. It was not possible to keep your back to the table, and it was forbidden to leave the table temporarily for all sitting people. During the general stay it was not necessary to stand in front of the older person who entered the room, as, according to the Adighe saying "the table is older than everyone". [8]

In the past, food was served on small round wooden tables with three legs (ane) which were perceived by foreigners as "trays on legs". And indeed, ane was brought already set, at the same time different dishes were served on separate tables according to the accepted order. On holidays and at the meeting of guests the number of ane could amount to tens. Spices and greens are used to give the dishes a good taste and aroma. Garlic salt (bzhynyfshchyguis) is a traditional Adighe seasoning.

In the national cuisine of the Adygeis the important place is occupied by millet. First of all, it was bread. In addition, various sweets, drinks, etc. were cooked from millet. One of the most common dishes made of millet is "paste", which is served for the second course instead of bread.

The Adygeis, like all peoples, observed a certain order of eating during the day. Food was generally prepared only for once just before the meal. If during the day it was necessary to have a snack, for this purpose there were always dairy products, Kalmuck tea, pastries, honey, nuts, etc.

The most affordable, everyday meat dishes were chicken and turkey dishes: chetlibj (roast of chicken) or thachetschips (turkey in sauce). 
A separate mention deserves thachet (turkey of a special Circassian breed). Indyuk (turkey), unlike chicken, is not everyday food. Dishes from turkey are prepared for guests of honor, as well as to mark any important events in life. Shchips (shchypsy) (sauce) along with Adighe cheese is considered a "visiting card" of national cooking. In auls shchips is daily food nowadays. There are many recipes of shchips, the subtleties of its cooking are given in families from mother to daughter, from grandmother to granddaughter.

The well-known fermented dairy product of Adighe cuisine is sour milk (shchkhyu). It is consumed without stirring to maintain a dense and resilient consistency. If you add garlic salt, pepper and some sour cream, you will get fermented milk sauce for meat dishes (shchkhyushchips) [1, 9 p.].

The Adygeis have long traditions of the technique of making cheese fresh. Adighe cheese is an indispensable basis for many national dishes such as koiazh (fried cheese with onions and red ground pepper), guubatt fillings (layered pies with cheese) and haluj (cheburek with Adighe cheese). A special type of Adighe cheese is smoked cheese. Today it is prepared in special smoke houses. And earlier it was prepared in the chimney (ondzhek), suspending braided baskets with cheese far away from fire. Such cheese has a unique taste and aroma, is stored for a long time. Cheese could always be obtained and served to the table with bread, Kalmuck tea and shchkhyu while the main dishes were prepared [3, 80 p.].

According to the laws of hospitality, Adighe should set the table for a guest at any time of the day, regardless of whether it is a welcome guest or not. As the travelers said, "it was possible to walk in Circassia without money in a pocket for months, nobody would let to die of hunger".

The Adygeis served food and drinks on a small table ane, it was impossible to lean on it. The place of the meal disciplined everyone, not allowing to drink excess. According to the Adighe saying "A real well-bred Dzhigit must leave the feast so that he could immediately attend for the same treat again".

Choreographic art of the Adygeis was born in deep antiquity. One of the first dances of the Adygeis that has survived to date is "udzh". It is like a choir. "Udzh" is performed, having taken hands, and moving in a circle in a certain rhythm. This dance usually ended every celebration and emphasized the unity of the assembled guests. Researchers highlight several traditional dances with a certain plastic pattern and individual rules (tlepechas, udzh, zafak, islamei). An expressive dance can show your feelings and attitude towards a person. The Adighe etiquette "adyge khabze" did not allow it to be done otherwise [3, pp.16-19].

This can be seen most vividly in the pair dances of the Adygeis. In the movements, the character of the Adygei man and the Adygei woman and their relationship are expressed. Thus, the main male qualities were nobility and restraint, and female qualities were sophistication and grace. Young people like to arrange "dzhegu". Dzhegu was a wide-scale game that, in a form that had been unchanged for many centuries, had been held by the Adygeis on various events, from the national to the family. Its scope was grandiose in terms of number of participants, duration and saturation of the program.

Dzhegu is performed at almost all solemn events. Here everyone can show the skill, ask the favorite girl for a dance. It is communication of the young Adygeis, expressed in traditional forms.

The Adighe culture is currently of genuine interest to representatives of other nationalities. The Adygeis have long traditions of ornamental and decorative art. With a variety of patterns, they decorate the interior of the housing, the national costume, the equipment of the horse, the weapons. Simplicity, clarity, beauty of ornament, its connection with form are distinctive features of works of folk creativity of the Adygeis [3, 1 p.]. 
Adygea, where the national peculiarities of this ethnic group are concentrated, from its cultural values of language, traditions, customs to the unique nature of human society, can be judged by a certain aura of this area, a specific local culture, which contributes to changes in spiritual, communicative and labor norms.

Further researches of scientists in the cultural sphere will contribute to the translation of the idea of translating of human consciousness into the unity with ethnocultural, social values into traditions. This will determine the nature of the evolution of spiritual culture, of the cultural connection of generations in the region.

\section{Лumepamypa}

1. Ивлиева О., Нечипорова Т. Туристско-рекреационный потенциал горной Адыгеи, Ростов-на-Дону: Южный Федеральный Университет, 2002. 7 с.

2. Корнакова Н.В. Наша Родина - Адыгея. Природа, население, хозяйство, история: учебное пособие. Ростов-на-Дону: БАРО-ПРЕСС, 2014. 448 с.

3. Кривов В.Д., Шкред К.В. Аналитическое управление аппарата совета федерации, аналитический вестник № 17 (616), «Современное состояние и перспективы социально-экономического развития Республики Адыгея» (к Дням Республики Адыгея в Совете Федерации). М., 2016. 616 с.

4. Локтева Ж.В., Петрушина М.Н., Мереминский С.Г. БРЭ-6. М., 2006. 767 с.

5. Меретуков М.А., Керашев А.Т. Культура и быт адыгов. Этнографические исследования. Майкоп: Адыгейское отделение Краснодарского книжного издательства, 1988. 334 с.

6. Меретуков М.А. Семья и брак у адыгских народов. Майкоп: Адыгейское отделение Краснодарского книжного издательства, 1987. 368 с.

7. Adygea Republic Russia. № 24, retrieved from, URL: https://russiatrek.org/adygeyarepublic.

8. Gammer M. Ethno-Nationalism, Islam and the State in the Caucasus: Post-Soviet Disorder, New York, Taylor \& Francis, 2008. 64-65 c.

9. Petrova Yu.A. Language consciousness as the peculiarity of cultural differences, retrieved from, URL: http://science-almanac.ru/documents/86/2016-02-11-Petrova.pdf, № 332.1, 2016. 3. c.

10. Petrova Y.A. Ethnography of communication // Гуманитарные и социально экономические науки. 2016. № 2. 90 с.

\section{References}

1. Ivlieva O., Nechiporov T. Turistsko-rekreatsionnyi potentsial gornoi Adygei. [Tourist and recreational potential of mountain Adygea], Rostov-on-Don: Southern Federal University, 2002. 7 p.

2. Kornakova N.V. Nasha Rodina - Adygeia. Priroda, naselenie, khoziaistvo, istoriia: uchebnoe posobie. [Our Homeland is Adygea. Nature, population, economy, history: tutorial]. Rostov-on-Don: BARO-PRESS, 2014. 448 p.

3. Krivov V.D., Shkred K.V. Analiticheskoe upravlenie apparata soveta federatsii. [Analytical Department of the Staff of the Federation Council], Analytical Journal No. 17 (616), "Sovremennoe sostoianie i perspektivy sotsialno-ekonomicheskogo razvitiia Respubliki Adygeia". [Modern State and Prospects of Social and Economic Development of the Republic of Adygea"] (to the Days of the Republic of Adygea in the Federation Council). Moscow, 2016. 616 p.

4. Lokteva Zh.V., Petrushina M.N., Mereminsky S.G. BRE-6. Moscow. 2006. 767 p. 
5. Meretukov M.A., Kerashev A.T. Kultura i byt adygov. Etnograficheskie issledovaniia. [Culture and life of the Adygeis. Ethnographic developments]. Maykop: Adighe branch of Krasnodar book publisher. 1988. 334 p.

6. Meretukov M.A. Semia i brak u adygskikh narodov. [Family and marriage of Adighe peoples]. Maykop: Adighe branch of Krasnodar book publisher. 1987. 368 p.

7. Adygea Republic Russia. No. 24. Available at: https://russiatrek.org/adygeya-republic.

8. Gammer M. Ethno-Nationalism, Islam and the State in the Caucasus: Post-Soviet Disorder, New York, Taylor \& Francis. 2008. pp. 64-65.

9. Petrova Yu.A. Language consciousness as the peculiarity of cultural differences. Available at: http://science-almanac.ru/documents/86/2016-02-11-Petrova.pdf, No. 332.1. 2016. 3 p.

10.10.Petrova Y.A. Ethnography of communication. Humanities and socio-economic sciences. 2016. No. 2. 90 p.

28 October, 2019 